Environment Conservation Journal 14(1\&2) 75-80, 2013

ISSN 0972-3099 (Print) 2278-5124 (Online)

Abstracted and Indexed

\title{
Influence of Glomus intraradices on growth, biochemical changes and withanolides content of Withania somnifera L Dunal (Ashwagandha)
}

\author{
Neelima Ratti $\bowtie$ and Avinash Upadhyay
}

Received: 21.11.2012

Accepted: 8.02.2013

\begin{abstract}
Withania somnifera L. Dunal (Ashwagandha) also known as Indian ginseng, of the family Solanaceae is an important ancient medicinal plant, used in the Indian traditional system of medicine. The medicinal importance of $W$. somnifera is attributed to the presence of steroidal lactones called withanolides which are present in the leaves and roots of the herb. The present set of pot experiment was designed to investigate the effect of Glomus intraradices inoculation on growth, biochemical parameters and withanolides content of $W$. somnifera. The results showed significant enhancement on plant growth, biochemical parameters and withanolide content in plant. Mycorrhizal treatment showed better vegetative growth in comparison to untreated plants. Significant increase in height, root length, and total dry weight (biomass) of AM inoculated plants as compared to non inoculated plants was observed. AM fungi considerably enhanced the levels of nitrogen, phosphorus and potassium as compared to that of non-mycorrhizal plants. A considerable increase in withaferin A and withanolide a content by mycorrhization was observed. Mycorrhizal inoculation significantly affected withanolide content of $W$. somnifera. The results suggested that $G$. intraradices is a beneficial biofertilizer for increasing yield of biologically important secondary metabolites in W. somnifera.
\end{abstract}

Keywords: Ashwagandha, Glomus intraradices, Withanolides, Withania somnifera, Arbuscular mycorrhizal fungi

\section{Introduction}

Withania somnifera (L.) Dunal (Family Solanaceae), commonly known as Ashwagandha, is one of the most valued medicinal plants with a number of pharmaceutical applications (Anonymous, 1962). The ethnopharmacological properties of this plant include adaptogenic, antisedative and anti-convulsion activities (Budhiraja et al., 2000). The plant is recommended in many Ayurvedic recipes and has been employed in the treatment of neurological disorders, geriatric debilities, arthritis and stress and behaviour related problems (Gupta and Rana, 2007). The medicinal importance of $W$. somnifera is attributed to the presence of steroidal lactones called withanolides which are present in the leaves and roots of the herb (Ichikawa et al., 2006; Misra et al., 2008).Plant roots interact with a wide variety of microorganisms in the soil, among these arbuscular mycorrhizal fungi form an important component of Author's Address

Hislop School of Biotechnology, Hislop College, Temple

Road, Civil Lines, Nagpur-(Maharashtra)

E-mail: neelimaratti2010@gmail.com soil microflora. Arbuscular mycorrhizal fungi develop a symbiotic relationship with higher plants, and have been reported to enhance the plant growth by supplying phosphate, nitrogen and other nutrients from the soil and translocating them to the host plant (Bolan, 1991).

Beneficial effects of AM symbiosis on plant growth, nutrient uptake, and tolerance to environmental stresses have been extensively reported (Koide and Mosse, 2004). However, these fungi show a preferential colonization to hosts and thus the extent to which the host benefit depends of the fungal species involved in the symbiosis (Miller et al., 1987).

The selection of efficient AM fungi is a key prerequisite for inoculation since there are different levels of compatibility between host plants and AM fungi (Smith and Read, 1997). The objective of the present study was to investigate the effect of Glomus intraradices on the growth and withanolide content of Withania somnifera under controlled environmental conditions. 


\section{Material and Methods}

Plant material and treatment of Glomus intraradices

Glomus intraradices was isolated from the rhizosphere soil of the plant and pure inoculum of the fungus was maintained on Rhodes grass roots in sterilized soil. A 90-days-old soil pot culture of $G$. intraradices maintained on Rhodes grass was used as inoculum. The infected root fragments and rhizospheric soil of the Rhodes grass containing 25 spores/g of soil was used as inoculum. Plants were harvested after 90 days. Dry weight of shoot, root and leaf was recorded after drying in an oven at $40^{\circ} \mathrm{C}$ for 7 days. Fresh weight of root, shoot, leaves and height of the plants was recorded at the time of harvesting.

\section{Plant growth conditions}

Surface sterilized seeds of Withania somnifera L. Dunal obtained from College of Horticulture, Mandsaur (M.P) were sown in earthen tray containing sterilized soil. The tray was inoculated with $10 \mathrm{~g}$ of soil-based AM inoculant (Glomus intraradices) containing approximately 250 chlamydospores of $G$. intraradices at the time of sowing. Seeds sown in sterilized soil without AM fungi served as controls. Twenty seeds were sown in each tray and were grown for 30 days in glasshouse with day/night regimes of $12 \mathrm{~h}$ at $30^{\circ} \mathrm{C}$ $\pm 2{ }^{\circ} \mathrm{C}$ and $45-60 \%$ relative humidity. Germinated seedlings were transplanted in earthern pots, one plant in a pot (6" size) filled with autoclaved soil (pH 8.0, EC $0.062 \mathrm{~ms} / \mathrm{cm}$, available $\mathrm{P} 0.12 \%$, organic carbon $0.79 \%$, nitrogen $0.06 \%$, potassium $0.87 \%$ ). There were five replicates for each treatment. Plants were watered when necessary. Roots of the seedlings were periodically checked for AM colonization by standard method of Phillips and Hayman (1970).

Analysis of phosphatase activity, macro and micronutrients, protein, chlorophyll content, crude cytokinin content and withanolides

Macro and micronutrients were analyzed from stem, root and leaf parts of the plant by the standard method of Jackson (1973). Assay of acid and alkaline phosphatase activity was done by the modified method of Bergmeyer (1974). Protein content was estimated by the standard method of Lowry (1951). Chlorophyll content was estimated by the age old method of Arnon (1949). Crude cytokinin was estimated by the method of Thiagarajan and Ahmad (1994). Withanolides were extracted from leaf and root of mycorrhizal and non-mycorrhizal plants by the method of Khajuria et al., (2004) and their qualitative analysis was done by reverse phase analytical high performance liquid chromatography (HPLC).

Percentage root colonization and number of spores/100 g soil

The root samples were stained with trypan blue in lactoglycerol by standard method (Phillips and Hayman, 1970). The percentage of infected root length was evaluated by the gridline intersect method of Giovannetti and Mosseae (1980). Spores were isolated from the soil samples by wet sieving and decanting method (Gerdemann and Nicolson, 1963 ) and quantified by eelworm counting slide.

\section{Results and Discussion \\ Effect of AM fungi on plant growth}

Inoculation of $G$. intraradices significantly affected plant growth, nutrient content, acid and alkaline phosphatases, protein and withanolides content of $W$. somnifera (Table 1-2, Fig. 1). AM fungi inoculation significantly enhanced shoot length, root length and dry weight of plant as compared to that of non-mycorrhizal control (Table 1). Percent increase in shoot length and root length of AM inoculated plants over control was $24.94 \%$, and $30 \%$, respectively. Total dry weight/plant of AM fungi inoculated plants was higher than control. Percent increase in total dry weight of mycorrhizal plant was $106.03 \%$. Earlier workers have reported significant increase in growth parameters due to mycorrhizal inoculation in medicinal plants (Earanna et al., 2002; Boby and Bagyaraj, 2003). Similar type of result was obtained by Haldar and Ray (2006) in W. somnifera inoculated with Glomus fasciculatum. Percent root colonization and number of spores in plants inoculated with Glomus intraradices was 63.84 and $188.14 / 100 \mathrm{~g}$ rhizosphere soil, respectively (Table 1). There was no AM fungi colonisation in control plants.

Effect of AM fungi on biochemical changes

There was a increase in chlorophyll a, chlorophyll b, total chlorophyll, protein, acid phos phatase,alkaline phosphatase and kinetinb content 
Influence of Glomus intraradices on growth

Table 1: Effect of G. intraradices inoculation on growth of Withania somnifera

\begin{tabular}{|l|l|l|l|l|l|}
\hline Treatments & Height $\mathbf{( c m )}$ & $\begin{array}{l}\text { Root length } \\
(\mathbf{c m})\end{array}$ & $\begin{array}{l}\text { Dry wt/plant } \\
\mathbf{( g )}\end{array}$ & $\begin{array}{l}\text { Percent Root } \\
\text { Colonization }\end{array}$ & $\begin{array}{l}\text { No. of spore/100 } \\
\text { g soil }\end{array}$ \\
\hline Control & $34.48 \pm 2.90$ & $6.0 \pm 0.38$ & $2.32 \pm 0.33$ & -- & - \\
\hline Mycorrhizal & $43.08 \pm 3.65$ & $7.8 \pm 0.49$ & $4.78 \pm 0.32$ & $63.84 \pm 3.28$ & $188.14 \pm 4.09$ \\
\hline $\mathrm{P}<0.05$ & 0.0033 & 0.0002 & $2.17 \mathrm{E}-06$ & $8.59 \mathrm{E}-11$ & $8.9 \mathrm{E}-14$ \\
\hline
\end{tabular}

$\pm=$ Standard Deviation

Table 2: Effect of $G$. intraradices inoculation on biochemical changes of Withania somnifera

\begin{tabular}{|l|l|l|l|l|l|l|l|}
\hline Treatments & $\begin{array}{l}\text { Protein } \\
\text { content } \\
\text { leaf } \\
(\mu \mathrm{g} / \mathrm{mg} \\
\text { fresh } \mathrm{wt})\end{array}$ & $\begin{array}{l}\text { Protein } \\
\text { content } \\
\text { root } \\
(\mu \mathrm{g} / \mathrm{mg} \\
\text { fresh } \mathrm{wt})\end{array}$ & $\begin{array}{l}\text { Alkaline } \\
\text { phosphatas } \\
\text { e activity } \\
\text { root }(\mu \mathrm{m} \text { p- } \\
\text { nitrophenol } \\
/ \mathrm{g} \text { fresh } \\
\mathrm{wt} / \mathrm{min})\end{array}$ & $\begin{array}{l}\text { Acid } \\
\text { phosphatase } \\
\text { activity root } \\
(\mu \mathrm{m} \text { p- } \\
\text { nitrophenol/ } \\
\mathrm{g} \text { fresh } \\
\mathrm{wt} / \mathrm{min})\end{array}$ & $\begin{array}{l}\text { Chl a } \\
(\mathrm{mg} / \mathrm{g} \text { fresh } \\
\mathrm{wt})\end{array}$ & $\begin{array}{l}\text { Chl b }(\mathrm{mg} / \mathrm{g} \\
\text { fresh wt })\end{array}$ & $\begin{array}{l}\text { Total chl } \\
(\mathrm{mg} / \mathrm{g} \text { fresh } \\
\mathrm{wt})\end{array}$ \\
\hline Control & $0.23 \pm 0.02$ & $0.15 \pm 0.004$ & $1.13 \pm 0.08$ & $26.47 \pm 2.03$ & $0.757 \pm 0.04$ & $0.442 \pm 0.024$ & $1.212 \pm 0.02$ \\
\hline Mycorrhizal & $0.46 \pm 0.01$ & $0.26 \pm 0.007$ & $2.32 \pm 0.09$ & $61.09 \pm 0.73$ & $0.810 \pm 0.04$ & $0.612 \pm 0.029$ & $2.012 \pm 0.18$ \\
\hline $\mathrm{P}<0.05$ & $1.06 \mathrm{E}-08$ & $8.81 \mathrm{E}-10$ & $1.94 \mathrm{E}-08$ & $4.32 \mathrm{E}-12$ & 0.081 & $7.1 \mathrm{E}-06$ & $9.13 \mathrm{E}-06$ \\
\hline
\end{tabular}

Figure 1. Withaferin A and Withanolide A content in mycorrhizal and non-mycorrhizal roots of Withania somnifera
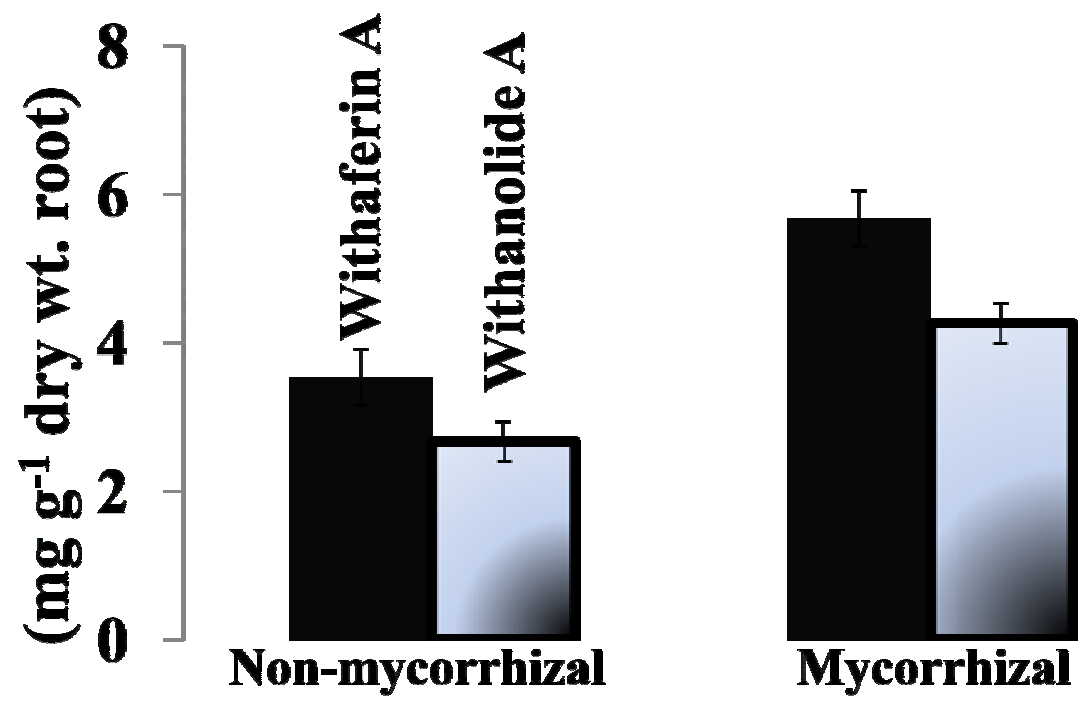
in AM fungi treated plants compared with nonmycorrhizal plants (Table 2). Inoculation of AM fungi increased $66.01 \%$ of total chlorophyll content as compared to that of control. Chlorophyll a was $7.0 \%$ higher in AM inoculated plants than that of control. The present results are in agreement with earlier workers who reported increased chlorophyll content in mycorrhizal plants (Morte et al., 2000).AM fungi colonization significantly increased production of acid and alkaline phosphatases (expressed as $\mu \mathrm{m}$ p-nitrophenol $\mathrm{g}^{-1}$ fresh wt $\mathrm{min}^{-1}$ of root tissue) as compared to that of non-mycorrhizal plants. Acid phosphatase activity was dominated over alkaline phosphatase in both the mycorrhizal and nonmycorrhizal plants. Acid phosphatase activity was $130.79 \%$ higher in AM inoculated plants than that of control (Table 2). The present results are in agreement with several authors who also observed increased activity of acid phosphatase and alkaline phosphatase in mycorrhizal roots as compared to nonmycorrhizal roots. Fries et al., (1998) observed that acid phosphatase and alkaline phosphatase activities in maize roots were closely correlated to levels of AMF colonisation of roots. Selvaraj (1998) found that due to inoculation of AM fungi G. fasciculatum acid phosphatase activity increased in leaves and roots of Prosopis juliflora. Higher uptake of phosphorus in mycorrhizal Withania somnifera plants may be due to the increased levels of phosphatase enzymes which ultimately resulted in enhanced growth response of plant. Mycorrhizal fungi have been reported to improve $\mathrm{P}$ availability by solubilising inorganic phosphorus which is mediated through release of organic acids and phosphatases (George et al., 1995). Earlier workers have suggested that alkaline phosphatase in mycorrhizal root played an important role in poly $\mathrm{P}$ degradation and thus the release of inorganic phosphate $(\mathrm{Pi})$ from arbuscules to root cells (Ezawa et al., 2001). Phosphorus translocated from external hyphae which is normally present in the form of polyphosphate can be hydrolysed by alkaline phosphatase.Leaf and root protein level expressed as $\mu \mathrm{g}$ protein $\mathrm{mg}^{-1}$ fresh weight of mycorrhizal inoculated plants showed a greater increase than the non-mycorrhizal plants (Table 2). Protein content of mycorrhizal plants was nearly two-fold than that of non-mycorrhizal plants. Mycorrhization increased $103.10 \%$ and $80.14 \%$ protein content in leaf and root over non-mycorrhizal plants (Table 2). The beneficial effect of mycorrhizal fungi on total protein content has been reported on plants of Catharanthus roseus inoculated with $G$. mosseae (Ratti et al., 2010). Accumulation of protein in the mycorrhizal roots has been reported in many plants (Gianinazzi-Pearson and Gianinazzi, 1989).

\section{Effect of AM fungi on nutrient content}

The effect of AM fungi in the total nitrogen, phosphorus and potassium content is presented in Table 3. Concentration of nitrogen, phosphorus and potassium in root and leaves of mycorrhizal plants was significantly higher than that of non-mycorrhizal ones (Table 3).

Table 3: Effect of G. intraradices inoculation on nutrient content of Withania somnifera

\begin{tabular}{|c|c|c|c|c|c|c|c|c|c|}
\hline \multirow[t]{3}{*}{ Treatments } & \multicolumn{9}{|c|}{ Concentration of nutrients (\%) } \\
\hline & \multicolumn{3}{|c|}{ Nitrogen } & \multicolumn{2}{|c|}{ hosphorus } & \multicolumn{2}{|c|}{ Potassium } & \multirow[b]{2}{*}{$\mathrm{R}$} & \multirow[b]{2}{*}{$\mathrm{L}$} \\
\hline & $\mathrm{S}$ & $\mathrm{R}$ & $\mathrm{L}$ & $\mathrm{S}$ & $\mathrm{R}$ & $\mathrm{L}$ & $\mathrm{S}$ & & \\
\hline Control & $\begin{array}{c}1.17 \pm \\
0.02\end{array}$ & $\begin{array}{l}1.43 \pm \\
0.02\end{array}$ & $\begin{array}{l}1.40 \pm \\
0.04\end{array}$ & $\begin{array}{l}0.11 \pm \\
0.02\end{array}$ & $\begin{array}{c}0.14 \pm \\
0.03\end{array}$ & $\begin{array}{l}0.18 \pm \\
0.03\end{array}$ & $\begin{array}{l}2.10 \pm \\
0.05\end{array}$ & $\begin{array}{l}1.53 \pm \\
0.04\end{array}$ & $\begin{array}{l}3.37 \pm \\
0.06\end{array}$ \\
\hline Mycorrhizal & $\begin{array}{l}1.97 \pm \\
0.10\end{array}$ & $\begin{array}{l}2.31 \pm \\
0.07\end{array}$ & $\begin{array}{l}2.25 \pm \\
0.09\end{array}$ & $\begin{array}{l}0.28 \pm \\
0.06\end{array}$ & $\begin{array}{l}0.31 \pm \\
0.03\end{array}$ & $\begin{array}{l}0.37 \pm \\
0.07\end{array}$ & $\begin{array}{l}3.52 \pm \\
0.04\end{array}$ & $\begin{array}{l}3.21 \pm \\
0.03\end{array}$ & $\begin{array}{l}5.55 \pm \\
0.07 \\
\end{array}$ \\
\hline $\mathrm{P}<0.05$ & $\begin{array}{l}1.6 \mathrm{E}- \\
07\end{array}$ & $\begin{array}{l}5.55 \mathrm{E}- \\
09\end{array}$ & $\begin{array}{l}3.85 \mathrm{E} \\
-08\end{array}$ & $\begin{array}{l}0.000 \\
242\end{array}$ & $\begin{array}{l}1.39 \mathrm{E} \\
-05\end{array}$ & $\begin{array}{c}0.000 \\
427\end{array}$ & $\begin{array}{l}2.64 \mathrm{E}- \\
11\end{array}$ & $\begin{array}{l}7.14 \mathrm{E} \\
13\end{array}$ & $\begin{array}{l}1.65 \mathrm{E} \\
-11\end{array}$ \\
\hline
\end{tabular}

S = Stem; R = Root; L = Leaf 
Mycorrhizal infestation increased $68.38 \%$, $60.71 \%$ and $61.54 \%$ nitrogen in stem, leaf and root as compared to non-mycorrhizal plants. Phosphorus content in stem, leaf and roots of mycorrhizal plants was $154.55 \%, 105.56 \%$ and $121.43 \%$ higher than non-mycorrhizal ones. The results of the present study coincide with the reported findings of Jackobsen et al., (1992), who have reported that the fungal hyphae growing beyond the rhizospheric soil increase the absorptive surface area of the root, which result in a greater efficiency of nutrient absorption, especially slowly diffusing mineral ions like phosphorus (Kothari et al., 1991). Transport of $\mathrm{P}$ into host plants and its release to root cells is an important function of AM fungi (Ryan et al., 2007). Increased $\mathrm{P}$ absorption is usually attributed to increased surface area and increased soil exploration by the root AM fungal association. Mycorrhizal fungi significantly increased potassium content as compared to that of non-mycorrhizal plants. Percent increase in potassium content of mycorrhizal plants was $67.62 \%$ in stem, $64.69 \%$ in leaf and $109.80 \%$ in roots as compared to that of non-mycorrhizal plants.

\section{Effect of AM fungi on withanolide content}

Mycorrhizal inoculation significantly affected withanolide content of $W$. somnifera (Fig. 1). The concentration of withaferin-A was $3.53 \mathrm{mg}$ and $5.67 \mathrm{mg} \mathrm{g}^{-1}$ dry weight root in nonmycorrhizal and mycorrhizal plants, respectively. Similarly the withanolide A content was $2.67 \mathrm{mg}$ in non-mycorrhizal and $4.26 \mathrm{mg}$ g-1 dry wt. in mycorrhizal plants (Fig 1). Percent increase in Withaferin-A was 60.62 and Withanolide-A was 59.55 as compared to that of non-mycorrhizal plants. The potential of AM fungi has been reported to enhance isoflavone content in red clover (Khaosaad et al., 2008). Results of the present study indicate that $G$. intraradices inoculation significantly enhanced plant growth, changed biochemical parameters and increased biologically active secondary metabolites in $W$. somnifera.

\section{Acknowledgements}

The authors are grateful to Department of Science and Technology, Govt. of India, New
Delhi for financial support under the Women Scientist Scheme and College of Horticulture, Mandsaur (MP) for providing the seeds of JA134 accession of Withania somnifera.

\section{References}

Anonymous 1962. The Wealth of India, PID CSIR: New Delhi; $37-38$.

Arnon D1. 1949. Copper enzymes in isolated chloroplasts. Polyphenoloxidases in Beta Vulgaris. Plant Physiology 24: $1-15$.

Bergmeyer UH. 1974. Methods of Enzyrnatic Analysis. NewYork: Academic Press, pp: 856-864.

Boby V U, Bagyaraj, D J. 2003. Biological control of root rot of Coleus forskholii Briq. using microbial inoculants. World $\boldsymbol{J}$ Microbiol Biotechn 19:175-180.

Bolan NS. 1991. A critical review on the role of mycorrhizal fungi in the uptake of phosphorus by plants. Plant and Soil 134, 189-207.

Budhiraja RD, Krishan P, Sudhir S. 2000. Biological activity of withanolides. J Sci Ind Res 59: 904-911.

Earanna N, Tanuja BP, Bagyaraj D J, Suresh CK 2002. Vesicular arbuscular mycorrhizal selection for increasing the growth of Rauvolfia tetraphylla. J Med Aromatic Plant Sci 24:695697.

Ezawa T, Smith SE, Smith FA. 2001. Differentiation of polyphosphate metabolism between the extra-and intraradical hyphae of arbuscular mycorrhizal fungi. New Phytol 149:555-563.

Fries L L M, Pacovsky R S, Safir G R, Kaminski J. 1998. Phosphorus effect on phosphatase activity in endomycorrhizal maize. Physiol Plant 103: 162-171.

George E, Marschner H, Jakobsen I. 1995. Role of arbuscular mycorrhizal fungi in uptake of phosphorus and nitrogen from soil. In: Critical Reviews in Biotechnology 15: 257270 .

Gerdemann JW, Nicolson TH. 1963. Spores of mycorrhizal endogone species extracted from soil by wet sieving and decanting. Transactions of the British Mycological Society 46: $235-244$.

Gianinazzi-PearsonV, Gianinazzi S. 1989. Cellular and genetic aspects of interactions between host and fungal symbionts in mycorrhizae. Genome 31:336-341.

Giovannetti M and Mosse B. 1980. An evaluation of techniques for measuring vesicular arbuscular mycorrhiza infection in roots. New Phytologist 84:489-500.

Gupta GL, Rana AC. 2007. Withania somnifera (Ashwagandha): a review. Pharmacognosy Rev 1: 129-136.

Halder S, Ray MB. 2006. Effect of VAM soil containing Glomus fasciculatum on growth of Withania somnifera Dun. Asian J Exp Sci 20(2): 261-268. 
Ichikawa H, Takada Y, Shishodia S, Jayaprakasam B, Nair MG, Aggarwal BB. 2006. Withanolides potentiate apoptosis, inhibit invasion, and abolish osteo clastogenesis through suppression of nuclear factor-kappaB (NF-kappaB) activation and NFkappaB-regulated gene expression. Molecular Cancer Therapeutics 5: 1434-1445.

Jackobsen I, Abbott LK, Robson AD. 1992. External hyphae of vesicular-arbuscular mycorrhizal fungi associated with Trifolium subterraneum L.: I. Spread of hyphae and phosphorus inflow into roots. New Phytol 120:371-380.

Jackson ML. 1973. Soil Chemical Analysis. Prentice Hall, New Delhi

Khajuria RK, Suri KA, Gupta RK, Satti NK, Amina M, Suri OP, Qazi GN. 2004. Separation, identification, and quantification of selected withanolides in plant extracts of Withania somnifera by HPLC-UV(DAD)-positive ion electrospray ionisation-mass spectrometry. J Sep Sci 27:541-546.

Kothari SK, Marschner H, Romheld V. 1991. Contribution of the VA mycorrhizal hyphae in acquisition of phosphorus and zinc by maize grown in a calcareous soil. Plant Soil 131:177-185

Koide RT, Mosse B. 2004. A history of research on arbuscular mycorrhiza. Mycorrhiza 14:145-163.

Lowry OH, Rosebrough NJ, Farr AL, Randall RJ. 1951. Protein measurement with the Folin Phenol reagent. Journal of Biological Chemistry 193: 265-275.

Miller RM, Jarstfer AG, Pillai JK. 1987. Biomass allocation in an Agropyron smithi - Glomus symbiosis. Am J Bot 74:114122.

Misra L, Mishra P, Pandey A, Sangwan RS, Sangwan NS, Tuli R. (2008). Withanolides from Withania somnifera roots. Phytochemistry 69: 1000-1004.
Morte A, Lovisolo C, Schubert A. 2000. Effect of drought stress on growth and water relations of the mycorrhizal association Helianthemum almeriense Terfezia claveryi. Mycorrhiza 10(3):115-119.

Phillips JM, Hayman DS. 1970. Improved procedures for clearing root and staining parasitic and vesicular arbuscular mycorrhizal fungi for rapid assessment of infection. Transactions of the British Mycological Society 15: 158161.

Ratti N, Verma HN, Gautam SP. 2010. Effect of Glomus species on physiology and biochemistry of Catharanthus roseus. Ind J Microbiol 50: 355-360.

Ryan MH, Mc Cully, ME, Huang CX. 2007. Relative amounts of soluble and insoluble forms of phosphorus and other elements in intraradical hyphae and arbuscules of arbuscular mycorrhizas. Funct Plant Biol 34:457-464.

Selvaraj T. 1998. Studies on mycorrhizal and rhizobial symbioses on tolerance of tannery effluent treated Prosopis juliflora. Ph.D. Thesis, University of Madras, Chennai, India, pp: 209

Smith SE, Read DJ. 1997. Mineral nutrition, heavy metal accumulation and water relations in VA mycorrhizal plants Mycorrhizal Symbiosis, 2 nd Ed., Academic Press, San Diego, CA, pp 126-160.

Thanasan Khaosaad, L. Krenn, S. Medjakovic, A. Ranner, A. Lossl, Monika Nell, A. Jungbauer, H. Vierheilig. 2008. Effect of mycorrhization on the isoflavone content and the phytoestrogen activity of red clover. J. Plant Physiol. 165: 1161-1167.

ThiagarajanTR, Ahmad MH. 1994. Phosphatase activity and cytokinin content in cowpeas (Vigna unguiculata) inoculated with a vesicular arbuscular mycorrhizal fungus. Biology and Fertility of Soils 17:51-56. 